\title{
Coinage of Yahya bin Ahmed: (The Origin and Imitation)
}

\section{Atef Mansour M. Ramadan ${ }^{\mathrm{I}}$}

Nașr bin AHmed (301-331H. / 913-943 A.D.) Put his brothers Abū Zakaraya YaHya, Abū ȘaleH Manșūr and Abū IsHaq 'Ibrahīm, in prison of Bukhara citadel. When he left Bukhara to go to Naysabūr, they were able to escape with the assistance of a man called Abū Bakr Al-Khabaz Al-'Asbahan̄i". ${ }^{1}$ When Al-Saaīd Naṣr bin AHmed was informed of the news about the revolution of his brothers under the leadership of Abū Zakaraya YaHya, he moved from Naysabūr to Bukhara. Abū Zakaraya YaHya gave the authority of GaīHūn River to Abū Bakr Al-Khabaz but he could not face the army of Al-Saaīd Nașr who captured him and crossed the river to Bukhara. He tortured Al-Khabaz then put him in the oven. Ibn Al-' Athīr mentioned that he was burnt ${ }^{(2)}$, but Al-Kardizì mentioned that they left him in a fired oven for a night. The next day they dragged him and his body was not burnt, sothe people were astonished ${ }^{(3)}$. Bartūld narrates: "The influence of Abü-Bakr on the public is reflected on the myth which claimed that his body was thrown in a flaming oven. When he was out the next day, he was found sound and was unharmed" ${ }^{(4)}$.

When Al-Saaīd Nașr occupied Bukhara, Abū Zakaraya YaHya moved to Samarqand, and then left to Balkh where Qarategīn joined Abū Zakaraya Yahya and they moved together to Marw. MuHamed bin Al-Mudhafar, the Samanid leader of

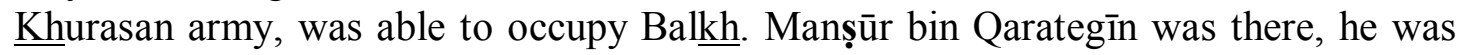
the one who escaped to Al Gūzgan. Al-Saaīd Nașr bin AHmed the authority of Balkh state and Takharestan to MūHamed bin Al-Mudhafar, who assigned his son as a ruler of it ${ }^{(5)}$. Abū Zakaraya YaHya headed to Naysabūr where Mākan bin Kālī was, so he prevented him to achieve it. MuHamed bin Ilyas joined Abū Zakaraya YaHya but he trusted Mākan bin Kālī, he rested in Naysabūr. Abū ȘaleH Manșūr and Abū 'IsHaq 'Ibrahīm trusted their brother Nașr bin AHmed. Abū Zakaraya YaHya was still on his revolution against his brother. When he failed to occupy Naysabūr, he went to Herat with Qarategīn. His leader Nașr bin AHmed followed them and MuHamed bin AlMudhafar joined them but YaHya and Qarategin moved again to Balkh. When Qarategīn was scared of meeting Al-Saaīd Nașr, he sent YaHya to Bukhara and he stayed in Balkh. Thus, Al-Saaīd Nașr bin AHmed moved to Bukhara following YaHya but YaHya escaped to Samarqand going to Naysabūr. MuHamed bin Ilyas had occupied it so he appointed YaHya bin AHmed as ruler and ordered to mention his name in the Friday cermon (El-Khutba) as a ruler. Both Abū Zakaraya YaHya and MuHamed bin Ilyas stayed in Naysabūr but Nașr bin AHmed moved to Naysabūr. When the revolutionists heard about this, they were separated; MuHamed bin Ilyas was oriented to Kerman, YaHya bin AHmed and Qarategīn moved to Bust and Rukhg, so they dwelled there. Nașr bin AHmed reached Naysabūr in year $320 \mathrm{H}$. and assigned the state of Balkh to Qarategīn. He felt safe for his brother Abū-Zkaraya YaHya. Thus his revolution ended ${ }^{(6)}$.

\section{History of YaHya bin AHmed Revolution in the Historical Sources:}

There is a lack of consensus among the historians concerning the beginning of the revolution. Al-Kardīzī mentioned that it started in year $317 \mathrm{H}^{(7)}$. Ibn Al- Ahtīr mentioned that the beginning of revolution was in year $317 \mathrm{H}$. He returned and

\footnotetext{
${ }^{\text {I }}$ Faculty of archaeology - Fayoum University
} 
mentioned that it started perhaps in year $318 \mathrm{H}^{(8)}$. He assured this date. Al-Nuwayrī agreed with Ibn Al-'Athïr that the date of the beginning of this revolution was year $318 \mathrm{H}^{(9)}$. As for the end date, it is agreed upon by both Ibn Al-' Athir and Al-Nuwayrī that it was in year $320 \mathrm{H}^{(10)}$.

Now, what are the struck coins during Yaha bin Ahmed revolution?
1- $\overline{\not E}$. Bukhara 315H(pl.1,Unpub. Tübingen EB6E2,w.2,39gr.) ${ }^{(11)}$. Obv.
Rev.

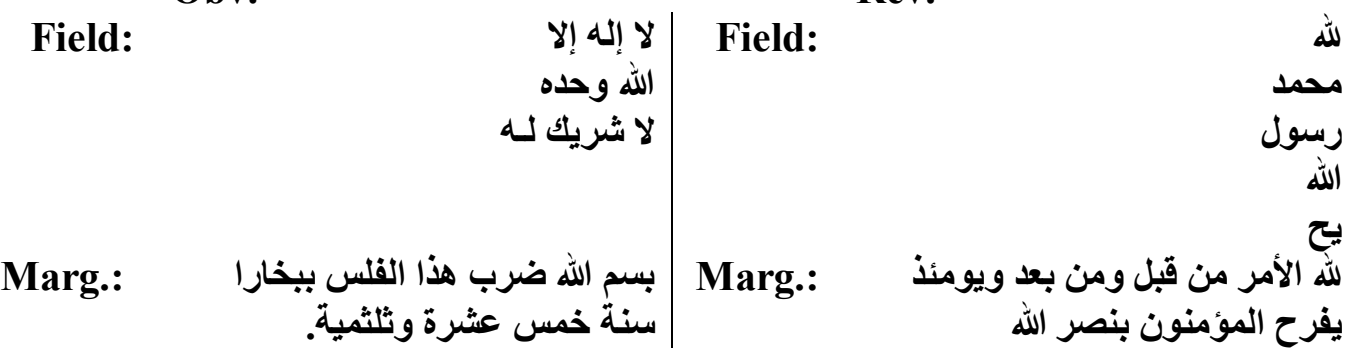

2- $\overline{\mathbf{E}}$. Bukhara 316H.: ${ }^{(12)}$ (As above but date is 316 H.)

Stephen Album indicated that the letters "y, $\mathbf{H}$ " refer to the name "YaHya bin AHmed" (13). These coins were classified in the collection of Tubingen University under the name of YaHya bin AHmed according to this opinion ${ }^{(14)}$. But I have some observations around the attribution of these follis to YaHya bin AHmed; firstly, concerning the letters "y, $\mathbf{H}$ " we can read "them as being the first letters of the name of YaHya, but We can read them also as "Bakh" بخ which is the acceptable reading for these two letters. Secondly: there is nothing that prevented YaHya bin AHmed from recording his name completely as "YaHya" or "YaHya bin AHmed" on these coins if he was the one who ordered to struck it. This seems important for the revolution of YaHya bin AHmed which started in Bukhara. There is no necessity to put only two letters from his name on these coins. Thirdly: the date of these coins is year $315 \mathrm{H}$ and $316 \mathrm{H}$. We have other types similar to this follis minted in Bukhara dated from the year $322 \mathrm{H}^{(15)}$ carrying these two letters " $\mathbf{y , \mathbf { H }}$ " or Bakh بخ. These dates, particularly $315 \mathrm{H}$. and $322 \mathrm{H}$, are not harmonious with the date of the YaHya bin AHmed revolution. Finally, these follis are from the usual issues for Bukhara Mint in the time of Nașr bin AHmed. Bukhara was the most important Mint for producing Samanid copper coins. Part of these issues dated from the year $315 \mathrm{H}, 316$ $\mathrm{H}, 322 \mathrm{H}$. We conclude at the end that the attribution of these coins to YaHya bin AHmed is doubtful and does not correspond with cash and historical hypothesis.

\section{3- AR. Samarqand 316 H. YaHya ibn AHmed (No description):}

This dirham is kept in the Museum of Hermitage. It is indicated by Markow. ${ }^{(16)}$ The date of the dirham (if correct $316 \mathrm{H}$ as mentioned by Markow) will determine the date of the beginning of the revolution which was controversial among historians as it is mentioned above. AR. Samarqand dirham clearly assured that the beginning of the revolution was in year $316 \mathrm{H}$, but the place of minting the dirham is Samarqand not Bukhara, where the YaHya bin AHmed revolution started. So I have doubts concerning the date of striking this dirham. It is the same dirham indicated by Tiesenhausen in 1871(NZ), he did read the date $306 \mathrm{H}$. The dirham is an imitation coin due to its indication by Tiesenhausen and found inside one of the Hoards in Russia which had moved to the Museum of Hermitage. Markow republished it 
another time and read the date $316 \mathrm{H}$. But this is a mere hypothesis of mine with no evidence. I failed to obtain the picture of this dirham to clarify the truth about this matter.

4- AR. Balkh 317H. Naṣr bin AHmed ${ }^{(17)}$.

Field:

Obv.

Rev.

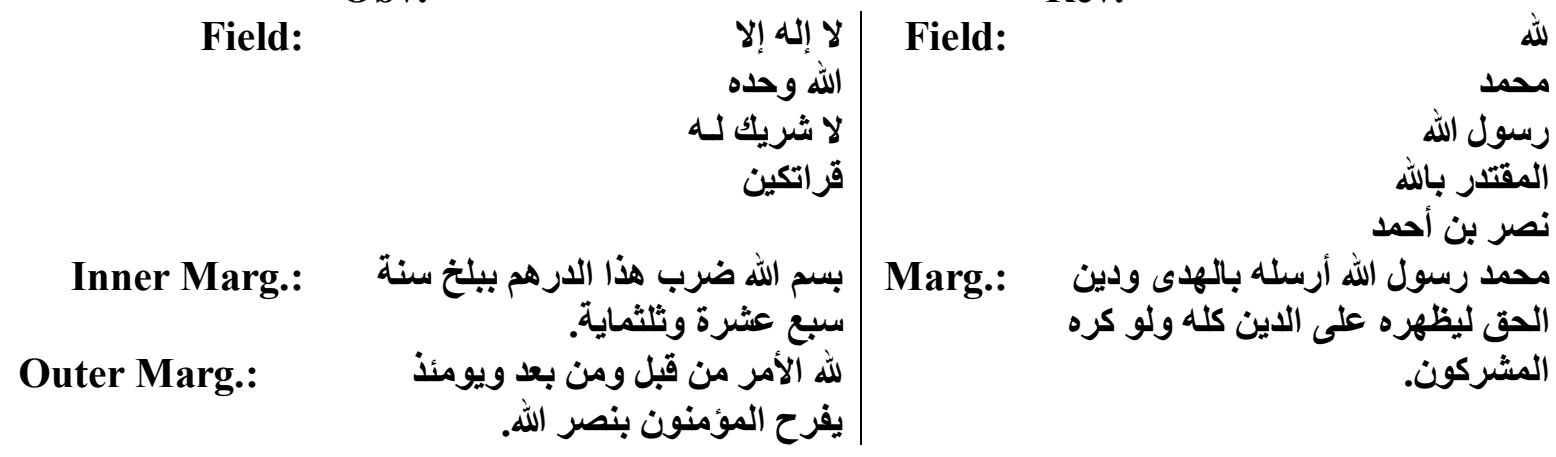

Florian Schwarz did read the name "Manșūr ibn AHmed" in the last line of the inscription of the center of the reverse; which refers to Abū Șaleh Manșūr ibn Ahmed, one of the revolutionists who participated with YaHya bin AHmed in his revolution against Nașr bin AHmed. Furthermore, the name of Qarategin was engraved in the fourth line in the obverse field. He was also one of the participants in YaHya bin AHmed revolution in Balkh. Qarategīn was a companion to YaHya bin AHmed and moved with him from Balkh to Marw, Herat and Naysabūr then Qarategīn returned back to Balkh and sent YaHya bin AHmed to Bukhara to make Naṣr bin AHmed too occupied to fight him in Balkh. Thus, Qarategin would better mention on this dirham the name" YaHya bin AHmed "and not "Manșūr bin AHmed" because YaHya is the head of the revolution joined by Qarategīn. But during my revising of the pictures of this dirham, it became obvious to me that the name is Nașr bin AHmed ${ }^{(18)}$. Thus, this dirham was struck by Qarategīn during his rule to Balkh for Nașr bin AHmed before joining the revolutionists under the leadership of YaHya bin AHmed. We can accept that Qarategin inscribing his name on this dirham was an expression of his desire for independence from Nașr bin AHmed. This desire of joining the YaHya bin AHmed revolution was asserted. This is after year $317 \mathrm{H}$ which was the date of minting the dirham. This assures that the YaHya bin AHmed revolution has started in year $318 \mathrm{H}$.

\section{5- AR. Bukhara 318H. YaHya bin AHmed ${ }^{(19)}$. (pl.2) Obv.} Field:

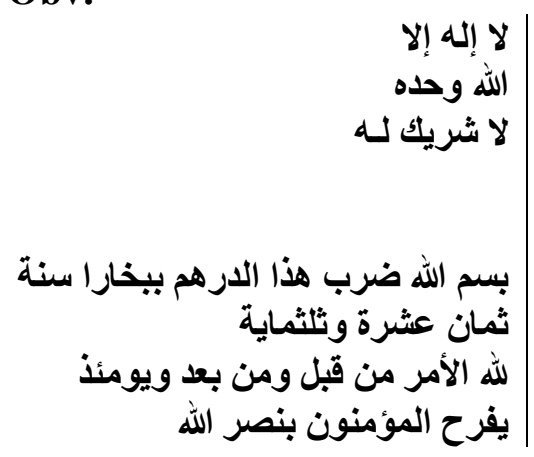

Rev.

Field:

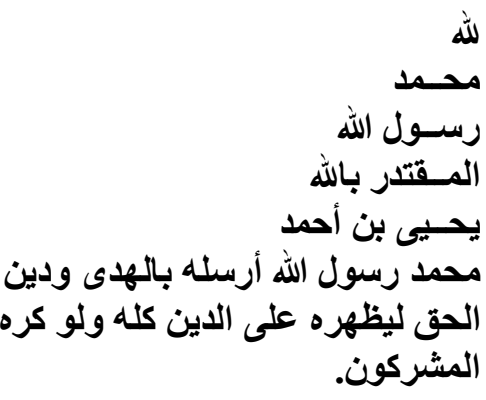

This dirham was struck in Bukhara in the name of "YaHya ibn AHmed" dated $318 \mathrm{H}$. All this is harmonious with the opinion of Ibn Al-' Athīr and Al-Nuwayrī that the YaHya bin AHmed revolution has started in Bukhara in the year $318 \mathrm{H}$. The time and place are completely harmonious with the historical events and what was 
mentioned by Ibn Al-' Athīr and Al-Nuwayrī. If the Samarqand dirham in year 316 was not correct, so the Bukhara dirham year 318 would be the first issue being minted by YaHya ibn AHmed in the beginning of his revolution in Bukhara in the year $318 \mathrm{H}$. Here the historical narrations will be harmonious with numismatics.

6- AV. Naysabūr 319H. Naṣr ibn AHmed ${ }^{(20)}$. (pl. 3)

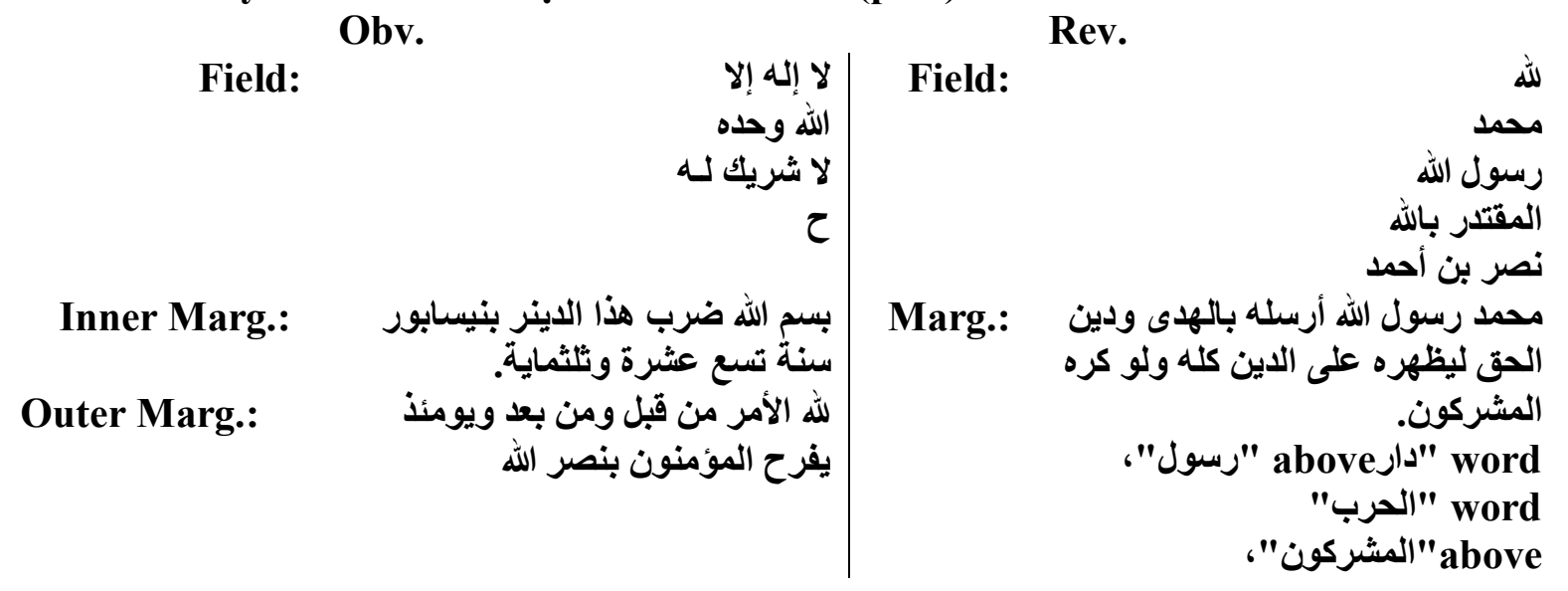

7- AV. Naysabūr 319H. Naṣr ibn AHmed ${ }^{(21)}$. (pl. 4)

These dinars in the name of Nassr ibn AHmed were struck in Naysabūr in 319H by Makan Ibn Kalī. It is related to the YaHya ibn AHmed revolution through the sculpture of the phrase "Dar El-Harb, War House" as a description to Naysabūr because it was a target to YaHya bin AHmed. He attempted to occupy it, but he couldn't because Mākān ibn Kālī prevented him to do so. Mākān ibn Kālī minted these dinars in the name of Nașr ibn AHmed to assure that Naysabūr is far from the hands of revolutionists. He indicated the danger of Naysabūr location by describing it as "the War House".

8- AR. Naysabūr 319H. MuHamed ibn Ilyas .Private collection in Qatar ${ }^{(22)}$. (pl.5)

Obv. Field:

Inner Marg.:

Mid. Marg.:

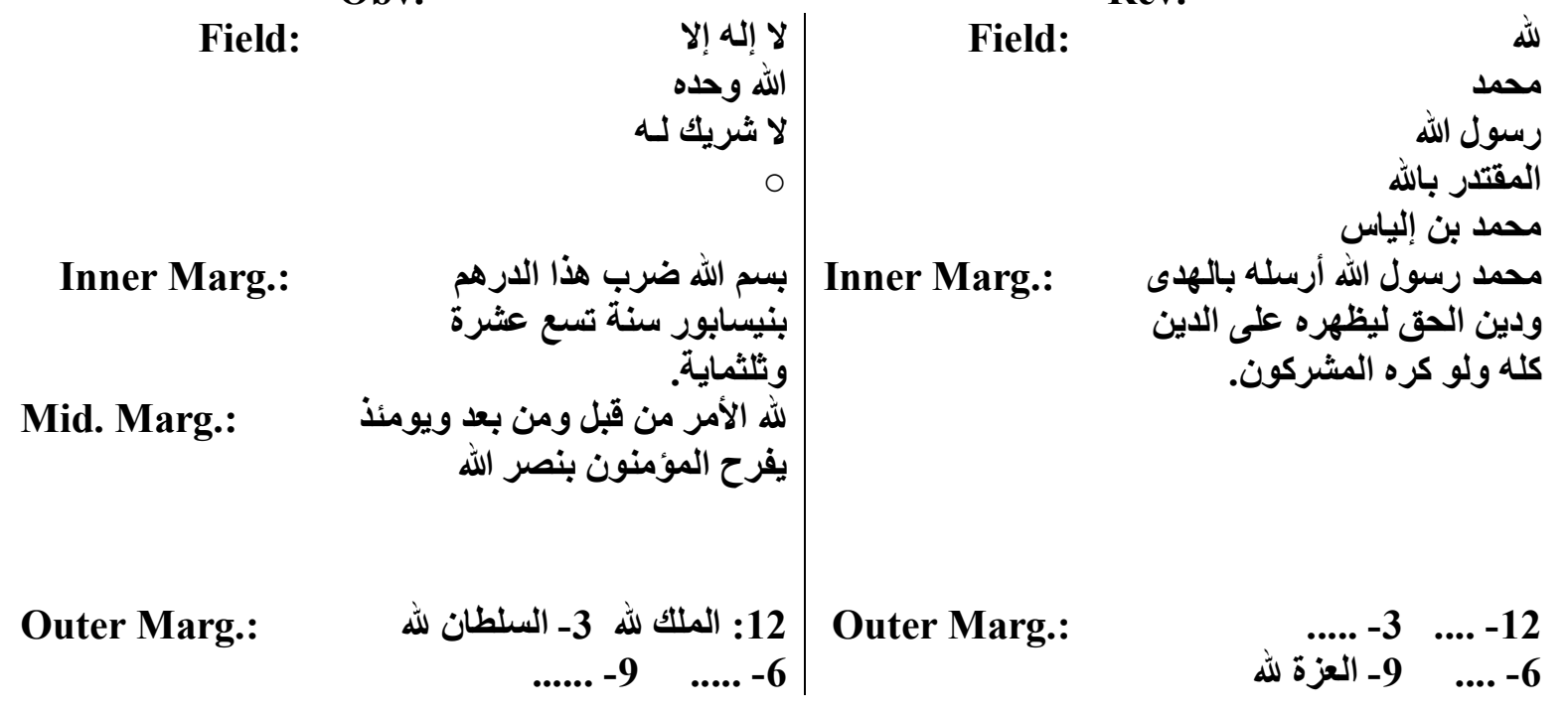

Rev.

This dirham is unique in the world and it is related firmly to the historical events of the YaHya ibn AHmed revolution. MuHamed ibn Ilyas was one of the friends of 
Samanid prince Nașr ibn Ahmed, but Nașr was angry with him and imprisoned him. MuHamed ibn 'Ubayd Allah Al-Balghamī mediated and he released him. He sent him to MuHamed ibn Al-Mudhafar in Jerjan ${ }^{(23)}$. When the brothers of Nașr ibn AHmed rebelled under the leadership of YaHya bin AHmed, MuHamed ibn Ilyas joined him. When YaHya was directed to Naysabūr where Mākān ibn Kālī was to occupy it, MuHamed bin Ilyas was with him. YaHya was not able to enter Naysabūr when Mākān ibn Kālī faced him, but MuHamed ibn Ilyas did not return with YaHya, He trusted Mākān ibn Kālī and he stayed in Naysabūr ${ }^{(24)}$. Mākān ibn Kālī went to Jerjan, MuHamed ibn Ilyas occupied Naysabūr. When YaHya ibn AHmed returned to Naysabūr another time, MuHamed ibn Ilyas submitted to him and ordered to mention his name in the Friday cermon (El-Khutba), and the coins were struck by his name. MuHamed ibn Ilyas and YaHya ibn AHmed stayed in Naysabur till the year 320H when Nașr ibn AHmed attacked Naysabūr. MuHamed ibn Ilyas escaped to Kerman and YaHya ibn AHmed stayed with his brother Nașr ibn AHmed ${ }^{(25)}$.

This dirham was struck by MuHamed ibn Ilyas in Naysabūr after the departure of Mākān ibn Kālī to Jerjan in the year $319 \mathrm{H}$. MuHamed ibn Ilyas occupied Naysabūr. "He is getting stronger ", Ibn Al-'Athīr mentioned. This dirham carries the name of MuHamed ibn Ilyas only. He didn't inscribe the name of YaHya ibn AHmed despite him joining the MuHamed to YaHya revolution and his attack on Naysabūr with YaHya. But after MuHamed ibn Ilyas' occupation of Naysabūr , this dirham was minted by his name individually, declaring his independence and revolution individually against prince Nașr. But after the arrival of YaHya to Naysabūr, MuHamed ibn Ilyas returned to join him another time.

9- AV. Naysabūr 319H.YaHya bin AHmed,Qatar Museum:W:4,30gr. D: 23 mm (26) (pl. 6).Tübingen.EB6E4.W:4,83gr.D:23 mm ${ }^{(27)}$. (pl.7)

Obv.

Field:
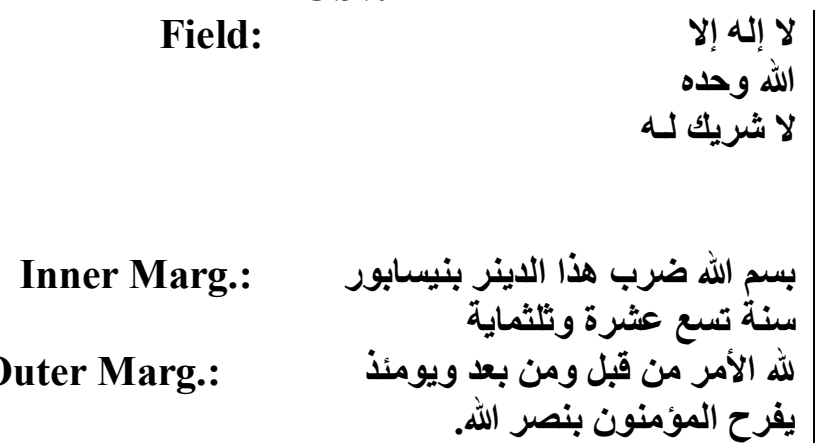

\section{Rev.}

Field:

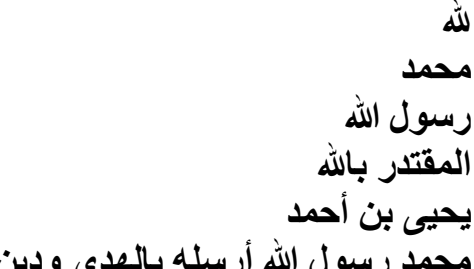

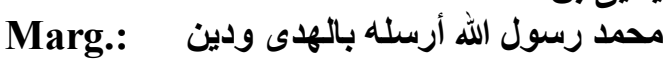
الحق ليظهره على الدين كله ولو كره المدئ

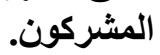

10- AV. Naysabūr 319H.YaHya bin AHmed,Baldwin,s Auctions, Jan.2007 ${ }^{(28)}$. (pl. 8). Basle 1986 ${ }^{(29)}$ (pl. 9):

as above but below obverse field.

\section{1-AR. Naysabūr 319H.YaHya bin AHmed ${ }^{(30)}$ : As No.9}

We return to the dinars and dirhams carrying the name of YaHya ibn AHmed being struck in Naysabūr in the year 319H. It was struck by YaHya himself after his occupation of Naysabūr where MuHamed ibn Ilyas ordered to mention his name in the Friday cermon (El-Khutba) and the coins were struck by his name. If looking at the coins that were struck in Naysabūr Mint in the year $319 \mathrm{H}$, we find it shedding light on these complicated historical events, as three different issues of coins were 
issued from Naysabūr carrying the date $319 \mathrm{H}$ recording on them the names of different rulers. The first issue includes dinars ${ }^{(31)}$ and dirhams ${ }^{(32)}$ in the name of Nașr bin AHmed. As for the second issue, it was the dirham which carried the name MuHamed bin Ilyas. The third issue includes dinars and dirhams in the name of YaHya bin AHmed. These Coins were struck immediately after the arrival of YaHya bin AHmed to Naysabūr as MuHamed bin Ilyas submitted to him till the year $320 \mathrm{H}$ when being occupied by Nașr bin Ahmed and minted in them the dinars ${ }^{(33)}(\mathrm{pl} .10)$ and dirhams ${ }^{(34)}$ to declare the return of Naysabūr under the control of the Samanid prince.

\section{Imitation of YaHya bin AHmed Coinage}

It is well-known that the Samanid Coins had obtained large fame in the world trade in the third and fourth Hegira century/ the ninth and tenth century A.D. The Samanid dirhams were particularly the most famous Coins in the cash and trade currency among middle Asia and Europe among the Bulghars, Russ and Saqalibh who had a big role in this trade ${ }^{(35)}$. There is no evidence but more treasures from these dirhams were found in Europe, more than 80,000 Kufic coins have been found in Scandinavia ${ }^{(36)}$. Bulghars were integrated with the Islamic world after their king converted to Islam during the reign of 'Abbasid Caliph Al-Muqtadir bi-Allah (295320H/908-932A.D) Asemissary ibn Faḑlan's responsibilities included representing the Caliph, reading letters aloud, presenting gifts and supervising the jurists and teachers whom the caliph had sent in response to the Bulghar king's request. The king of Bulghar (Yiltawar) chose to change his and his father's name to the Muslim names "Ga far bin 'Abd-Allah" as a good omen for the name of the 'Abbasid Caliph Ga far Al-Muqtadir ${ }^{(37)}$.

Al-Kirdizī mentioned about the Bulghars:

$$
\begin{aligned}
& \text { "ولباسهم يشبه لباس المسلمين، وقبورهم تشبه قبورهم، وأكثر أموالهم فراء القاقم، ولبيس لهم صامت (38)، وهم }
\end{aligned}
$$

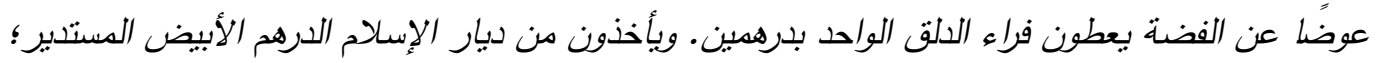

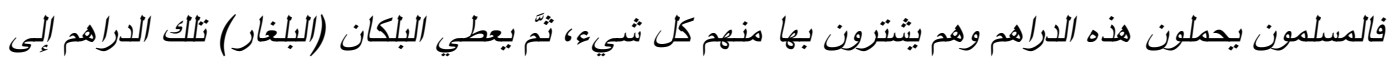

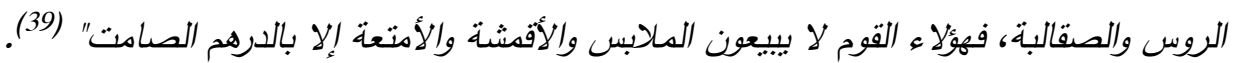

"Their clothes are similar to the Muslim ones. Their tombs are similar to theirs, most of their money is the fur of Qaqem and they have no silver, gold or jewels. As a parter of silver, they give the fur of Dalq. One dirham equals two dirhams. They take from Islamic lands the white circled dirham. Muslims carry these dirhams buying everything from them, and then the Bulhgars give these dirhams to the Russ and Saqalibah. Those people do not sell the clothes, textiles and goods but for a silent dirham".

Ibn Faḍlan also said that about Russ: 'Their women wore metal boxes and other jewelry, including metal necklaces (a status symbol and convenient alternative to their preferred currency, dirhams from the Muslim world) and ceramic beads (presumably amulets against the evil eye).' This important historical text assures the significant role played by Bulghars as mediators in trade between Muslims, Russ and Saqalibah. Bulghars were using Islamic dirhams in trade with Russ and Saqalibah. Russ and Saqalibah were not selling their products to Bulghars except forIslamic dirhams. The embracement of Islam and the large trade co-operation with Muslims had encouraged the Bulghars to learn how to strike coins, and hence their imitation of Islamic Coins, 
particularly the Samanid dirhams. The imitated Coins were used mainly in trade with Russ and Saqalibah who were not selling their products except for Islamic dirhams. This essentially made the many mistakes appearing on the imitated Coins acceptable because their dealers or those who started to circulate them, did not realize or know those mistakes.

The imitations of Samanid Coins could be divided into two divisions ${ }^{(40)}$ :

- The First division: The imitated Coins in the name of Samanid Rulers. This division includes the imitated Coins for the Samanid Coins as complete imitation. It shows the names of Samanid rulers beside the existence of mistakes in the writting of Arabic letters, and in the names of Samanid rulers and the periods of their reigns and also the names of 'Abbasid Caliphs and the periods of their rulings.

- The Second division: The imitations of Samanid Coins, with the names of Bulghar princes. It was struck in the same general design of Samanid dirhams; however they carry the name of one of the Bulghar princes. We can divide these coins into two types:

The first type: the completely imitated dirhams for Samanid dirhams showing on them only the name of the Bulghar prince, such as the dirham of Michael bin Ga'afar. It carries the names of Samanid Mint, such as: Samarqand (pl.11), Naysabūr (pl.12), Al-Shash and without mint or date (pl.13, 14).

The second type: the imitated dirhams for Samanid dirhams. It carries the name of the place where it was struck in Bulghar mints such as Bulghar or Sewar. There are the names of Bulghar princes on them such as Yaltwar (Barman), Michael bin Ga'afar, Ṭaleb bin AHmed, Mū 'men bin AHmed and Mū 'men bin Al-Hassan.

In this research we will add a third division or an important new type which is the imitation of Samanid revolutionist's coins.

The Samanid era had witnessed many revolutions by princes from the Samanid dynasty ${ }^{(41)}$. They were refusing the assignment of one of the Samanid princes and they were greedy in making the assignment for themselves or the independence by ruling some of the Samanid states. The revolutionist occupied one of these states or big cities and he inscribed his name on the coins in the mints to assure his revolution and his right in its assignment. His coins have circulated inside these states that had been occupied. We have many revolutionists from the Samanid era, such as: IsHaq bin AHmed who ordered to strike dinars (pl.15) and dirhams (pl.16) in Samarqand $(301 \mathrm{H})$ and Naysabūr in the year $301 \mathrm{H}$ (pl. 17 ), YaHya bin AHmed (316-320 H) who minted his coins in Bukhara, Samarqand and Naysabūr, MuHamed bin Ilyas $(319 \mathrm{H}, 327-355 \mathrm{H})$ minted his coins in Naysabūr and Kerman, and 'İbrahīm bin Ahmed (335-336 H) who minted his coins in Naysabūr and Samarqand.

As these revolutionists belonged to the Samanid family, it gave their coins some of legislation in circulation at least during their revolutions times. 
Thus, the coins of these revolutionists were used in trade like the legislative Samanid coins or perhaps due to the carefulness of their dealers to get rid of them quickly through their treatments with Bulghars. Perhaps they were accepting the coins of these revolutionists because they did not know the truth of the matter or because the matter itself did not mean anything, because they would transfer these coins to the Russ and Saqalibah. This attitude was supported by the big quantity of Samanid revolutionist coins found in Europe ${ }^{(42)}$. This assures the transfer of these coins through commercial dealings between Bulghars, Russ and Saqalibah or others. Perhaps the Bulghar princes were accepting the coins of these revolutionists, whether knowing or not knowing, due to their imitation of the coins of one of the revolutionists; YaHya bin AHmed. These coins were found inside the discovered hoards in Europe. This confirms the circulation of these coins within the European territories. Any specimen is not found in Samanid hoards were discovered in the east. Surely, these imitated coins were traded with Russ, Saqalibah and others. They were not traded with the Samanid country which rulers would refuse the acceptance of one of the revolutionist Coins. Some would refuse the circulation of these Coins as well because they would not be accepted in currency inside the Samanid territories. It is something wonderful that these coins giving us the rare specimen represent an imitation of the coins of one of the Samanid revolutionists who is YaHya bin AHmed.

1- AR. Binkath 306H. YaHya bin Ahmed. pl. 18 .SHM 8671 unpub. w.3.45gr Obv.

\begin{tabular}{|c|c|}
\hline $\begin{array}{r}\text { Field: } \begin{array}{r}\text { within } \\
\text { circle }\end{array}\end{array}$ & لالا شله وحله إلاه \\
\hline Inner Marg.: & ستم واللثماية ضرب هذا الدرهم ببنكثا سنة \\
\hline Outer Marg.: & للفرح الأمر من قبل ومن بعد ويومئذ \\
\hline
\end{tabular}

Field: within double circle Rev.

Marg.:

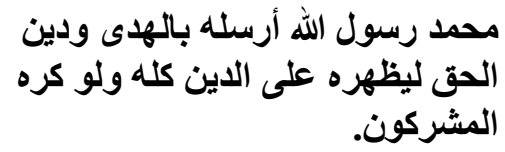

2- AR. Samarqand 290H YaHya bin Ahmed. ${ }^{(43)}$ pl.19,DE. Museum unpub.w.3.01gr,D.29.mm. ${ }^{(44)}$. pl. 20. SHM 7063 unpublished w.3.40gr, pl. 21. SHM 16200 unpub. w.3.12gr, pl. 22,Fragment,SHM 14782 unpublished. w.1.52gr.

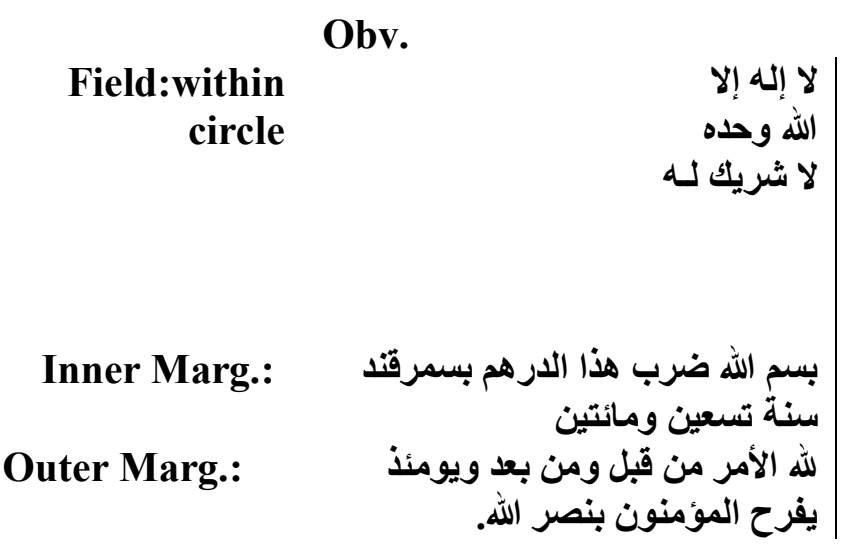

Field: within circle

Rev.

Marg.:

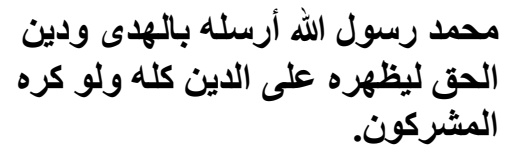


It is to be noted that most of the dirhams discovered in Europe are fragments. This confirms that these dirhams were cut and fragments were used in simple trade deals as undervalued more than the dirham. This happened also in many Islamic countries due to the non-availability of helpful coins as copper coins ${ }^{(45)}$. The availability of these fragments proves the popularity of YaHya ibn AHmed dirhams in circulation as well as the legislative Samanid dirhams. These dirhams were broken and were traded by its parts. It is sure that the availability of a fragment of dirham minted in Naysabur 301H in the name of the revolutionist IsHaq ibn AHmed (pl.17).

3- AR. Samarqand 290H. YaHya bin Ahmed. pl. 23 .SHM 3547 unpublished:As above but without circle around Obv.Field.

4- AR. Samarqand 290H. YaHya bin Ahmed. pl. 24.SHM 28831 unpublished w.2.84gr: As No.2 but double circle around Rev.Field.

5- AR. Samarqand 290H. Hybrid Obv. YaHya bin Ahmed.Rev. AHmed bin 'İsma īl , pl. 25. SHM 13967 unpublished. w.2.52gr

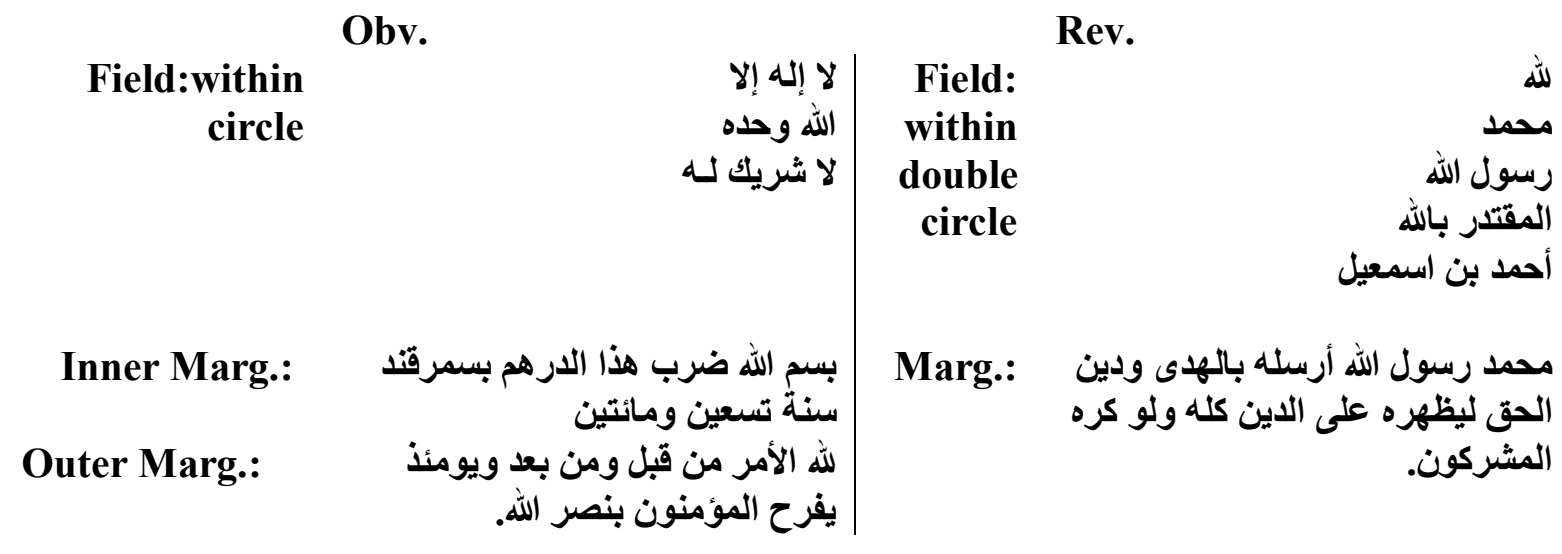

6- AR..Samarqand 299H ${ }^{(46)}$.

Stephen Album referred to Samarqand mint dirham in the year $299 \mathrm{H}$ and mentioned, "Maybe old obverse die of Samrqand 299H used to strike this dirham, or possibly a contemporary imitation". I asked Stephen Album about this dirham and its source, but he didn't give me any information about this dirham and the place of its availability. This let me to doubt its availability originally. Perhaps Album referred to the Samarqand dirham in the year $290 \mathrm{H}$.

7- AR. Samarqand 306H. YaHya bin Ahmed ${ }^{(47)}$.

Obv.

Field:

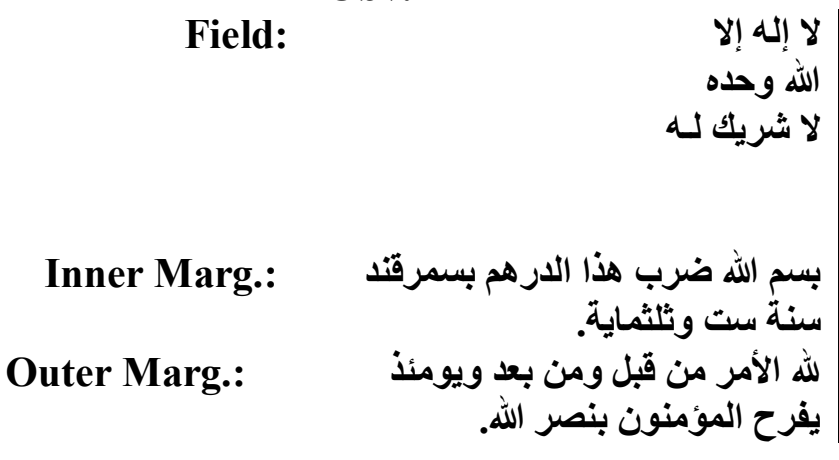

Rev.

Field:

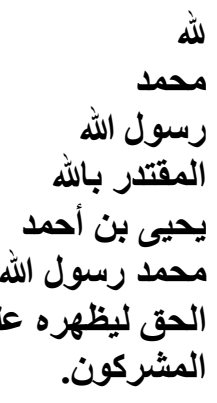


I do not know the destiny of this dirham found in Russia. Was it transferred to the Hermitage Museum, being republished by Markow who read the date as $316 \mathrm{H}$ ? This three issuances being minted as an imitation for YaHya bin AHmed coins are considered evidence for the circulation of Samanid revolutionist coins side by side with the coins of legislative Samanid land. This dates back to the first level to the circulation of these coins out the Samanid territories borders, and the non -knowledge or care for the dealers of this coin to the names of rulers inscribed on them because their non-knowledge of Arab language and also their non-knowledge of the contemporary Samanid rulers. Perhaps what confirmed this were the many linguistic mistakes on these imitated coins and also the mistakes in the inscription of the Samanid rulers' names or the 'Abbasid Caliphs and the periods of their ruling. This led to the circulation of revolutionists' coins and the legislative rulers being an acceptable matter. 


\section{Notes}

1 Al-Kardiz̄̄ (Abū Sa ‘̄id Abd el-Hāi ibn Al-DHāk ibn MaHmūd 442-443H. ), Zayn Al akhhbar, translated: 'Afaf Al-Sayed, two Parts , Cairo, first edition, 1402H./1982A.D., Part 1, 243; Ibn Al'Athīr('Ali ibn MuHamed 630H.), Alkāmil fi Altārkh , vol. 11, Beirūt, $3^{\text {rd }}$ edition, 1418H./1998 A.D. Vol. 7, 54, Al-Nuwayrī (AHmed ibn 'Abd el Wahab 733H.), Nihayat Ala'rab fì Finon Ala'dab, Vol. 25, Cairo, 1404H./1984 A.D., 343.

${ }^{2}$ Ibn Al-'Athīr, Alkāmil fì Altārkh, Vol. 3, 55. Al-Nuwayrī, Nihayat Ala'rab fï Finon Ala'dab, Vol. 25, 348.

${ }^{3}$ Al-Kardizī, Zayn Al akhbar, Part I, 244.

${ }^{4}$ Bartūld, V.V., Turkestan men Al FatH Al'Arabī 'Ila Al ghazo Al magholi, translation, ȘalaH Al-Din Ūthman Hashim, Kūwait, 1401H./1981A.D, 373.

${ }^{5}$ Ibn Al-'Athīir, Alkāmil fi Altārkh, Vol. 7, 55-56.

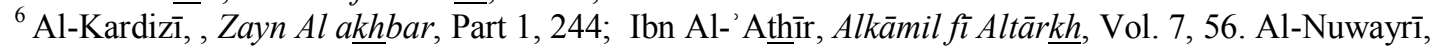
Nihayat Ala'rab fi Finon Ala'dab, Vol. 25, 348; .Bartūld, 373.

${ }^{7}$ Al-Kardizī, Zayn Al akhbar, Part I, 243.

${ }^{8}$ Ibn Al-'Athīr, Alkāmil fì Altārkh, Vol.7, 54.

${ }^{9}$ Al-Nuwayrī, Nihayat Ala'rab fì Finon Ala'dab, 347.

${ }^{10}$ Ibn Al-'Athīr, Alkāmil fì Altārkh, Vol.7, 56. Al-Nuwayrī, Nihayat Ala' rab fì Finon Ala'dab, 348.

${ }^{11}$ Fraehn,Chr.Mar., Recensio Numorum Muhammedanorum, Petropoli 1826, 87, No. 219; Fraehn, Chr Mar., Die Münzen der Chane Vom ulus Dschutschi's oder von der Goldenen Horde, nebst denen Verschiedener anderen Muhammedanischen Dynastien Im Anhange; aus der ehemaligen Sammlung des H. C. Von Fuchs Zu Kasan, Jetzt der Kois, Universitat Daselbst Gehörig. In Kurzen Andeutngen und Nachweisungen. ST. Petersburg/Leipzig 1832, 50, No. 419, pl. XIV, No. XII; Dorn, B., Inventaire des Monnaies des Khalifes Orientaux et de Plusieurs autres dynasties, Saint Petersbourg, 1881, 103,

No. 122-123; Oliver, E.E., "The Decline of the Samanis and the Rise of the Ghaznavis in Mawara unNahr and Part of Khurasan: (with some unpublished coins)", Journal of the Asiatic Society of Bengal, Calcutta 55 (1886/1887), 89-135, pls. 1-3, 128, No. II, pl. III, Rispling, Table, No.3-6

${ }^{12}$ Tübengen: EB6E3; Fraehn, Recensio Numorum Muhammedanorum, 87, No. 221; Dorn, Inventaire des Monnaies des Khalifes Orientaux, 104, No. 126, Rispling, Table, No.7-8

${ }^{13}$ Album, Stephen, A Checklist of Islamic Coins, (2 ${ }^{\text {nd }}$ ed.), 1998, 71, No. 84.

${ }^{14}$ I discuss this attribution with Dr. Ilisch Lutz, he mentioned: As this was going back to a coin from my collection, which came originally from the Hollschek collection with attributions by Eduard von Zambaur made around 1900, I tried to check what had happened. Zambaur had attributed the falls as anonymous to Nasr ibn Ahmad, when I got the coin in 1972. Then I added as reference of Elena Davidovich, "Novye dannye po istorrii Samanidov (Klad mednykh monet IX-Xvv. iz Samarqanda)", Srednaya Aziya i drevnosti i srednevekov'e, Moscow 1977, 112-125; where such coins equally had been attributed as anonymous to Nasr. I just don't recall what made me later (before 1991).change the attribution to Yahya ibn Ahmad with a question mark. It was certainly not a misreading of the clear bakhkh as yah or the like, rather the idea that the anonymous coinage leaving away the name of Nasr. ${ }^{15}$ Lane - Poole, Stanley, Catalogue of Oriental Coins in the British Museum, Vol. IX: Additions to Vols. I - IV, London 1889, 182, No. 356i; Nicol, N.- El Nabarawy, R. - Bacharch, J., Catalog of The Islamic Coins, Glass Weights, Dies and Medals in The Egyptian National Library, Cairo, American Research Center in Egypt, 1982, No. 4547.

${ }^{16}$ Markow, A., Inventorny Katalog Musulmanskich Monet, Saint-Petersburg 1896, 142, No. 730- 731; Zambaur, E., Die Münzprägungen des Islams, Band I, Wiesbaden 1968,148- 149, Not. 24.

${ }^{17}$ Schwarz, Florian, Sylloge Numourum Arabicorum Tübingen: Balh und Die Landschaften AM Oberen Oxus XIVc Hurasan III, Ernst Wasmuth Verlag Tübingen, Berlin 2002, 76, No. 579, pl. 32.

${ }^{18}$ I would like to give my special thanks Dr. Ilish Lutz for his help, in re-reading the piece according my opinion, and then he corrected the name to "Nașr ibn AHmed".

${ }^{19}$ Vasmer, Richard, Der Kufische Müzfund von Friedrichshof in Estland, Sitzungsberichte der Gelehrten Estnisechen Gesellschaft (Dorpat) 1925 (1927) [pp. 26- 118], 99, No. 665(W.2.58 gr.,D.29mm.); Vasmer, Richard, Dava Klada Kufiçeskich Monet, Leningrad 1927, pl.II, w. Busso Peus Nachf, Auction 382, Antike Islam, April 2005, Lot 822 (W.2.95 gr.).

20 'Ibrāhīm Gābir Al- Gābir, Alnqūd Al'Arabia Al 'I slāmya, Vol.3, Al-DoHa, 2005, No.3700.

${ }^{21}$ Al- Gābir, Alnqūd Al'Arabia Al 'I slāmya, No.3701- 3702.

${ }^{22}$ Ramadān, 'Āṭif Manșūr, "A Rare Dirham minted in Naysabūr 319H in the Name of MuHamed ibn Ilyas", in: The festschrift of Late Samir Shamma (Unpublished).

${ }^{23}$ Ibn Al-' Athīir, Alkāmil fí Altārkh, Vol.7, 96 
${ }^{24}$ Ibn Al-' Athīir, Alkāmil fì Altārkh, Vol.7, 55-56

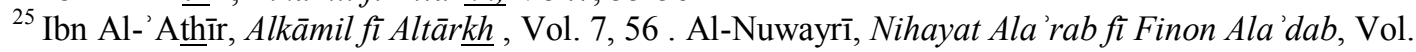
25,348

${ }^{26}$ Al- Gābir, Alnqūd Al 'Arabia Al 'I slāmya, 127, No.3703

${ }^{27} \mathrm{Sa}{ }^{\text {'īd }}$ 'Abdel-FatāH 'Afîfi 'Ațâllah, Nqūd Naysabūr mundh Al FatāH Al 'I slāmī Hatta Sqūt Al dawla Al-Khāwarizmya, unpublished Ph.D. dissertation at Faculty of Archaeology, Cairo University, 2003. 290-291, pl. 78; Album, A Checklist of Islamic Coins, 71, No 1453.

${ }^{28}$ Baldwin's Auctions LTD., Dimtry Markov Coins \& Medals, M.X.M Numismatics LTD, The New York Sale XIV, January $10^{\text {th }} 2007$, Lot. 529. W.4.35 gr.D.24mm.

${ }^{29}$ Lutz,Ilisch, Action Catalogue 69 of Muenzen und Medaillen AG,Basle, October 1986, 21, No.126.

${ }^{30}$ Fraehn, Chr. Mar., "Der Orientalische Münzfund Von Essemeggi in Ehstland, Ein Nachtrag Zu der Topographischen übersicht der Ausgrabungen Von Alten Arabischen Gelde in Russland", Bulletin de La Classe Historico-Philologique de L'Acadadémie Impériale des Sciences de ST. Petersbourg 5, 1848 [Cols 113- 122], 119, No. 20; Tornberg, C. J., Numi Cufici Regii Numophylacu Holmiensis, Upsaliae 1848, 212, No. 400, pl. XI; Fragment, but Mint Oblieted; Dorn B., "Über dritte dem Asiatischen Museum in J. 1869 Zu Gekommene Münzerwerbung”, Melanges Asiatiques Tires du Bulletin de L'Academie Imperiale des Sciencs de ST. Petersbourg 6, 1869- 1873 (1873) [pp. 187- 194], 194, No. 77; Markow, Inventorny Katalog Musulmanskich Monet, 142, No. 732- 733.Leimus, Ivar, Sylloge of Islamic Coins Estonian public collections, Tallinn 2007, 404, No.3373, pl.140.

${ }^{31}$ Dinars Naysabūr 319 H. in the name of Nașr ibn Ahmed; Nașer Al-Naqshabandī, "Al dinār Al islāmî”, Sumer, vol. 3, 1947, 287; Al- Gābir, No. 3700-3702; Lane-Poole, Vol. IX, 181, No. 294 b. But read date "تسع و عشرين وثلثمائة"-; Sotheby, Islamic, Ancient, English and Foreign Coins and Banknote, Tuesday $16^{\text {th }}$ April, London, 1985. No. 167.

${ }^{32}$ Dirham Naysabūr 319H.in the name of Nașr ibn AHmed: Markow, Inventorny Katalog Musulmanskich Monet, 134, no.565.

${ }^{33}$ Dinar Naysabūr 320H. in the name of Nașr ibn AHmed: 'Atallah, 206; Ghouchani, 'Abdullah, Ray Hoard of Nishabur Dinars, Tihran, 1383 H. Sh, No. 201. Al- Gābir, Alnqūd Al'Arabia Al 'I slāmya, No.3705 (W.4.28 gr., D.24mm.)

${ }^{34}$ Dirham Naysabūr 320H. in the name of Nașr ibn AHmed :Tornberg, C.J., Symbolae Ad Rem Numariouam Muhammedanorum, Upsale 1862, Iv, 34, No. 100; Markow, Inventorny Katalog Musulmanskich Monet, 135, No. 570; Lane-Poole BM, Vol. IX, 182, No 333 b.

${ }^{35}$ Amīn Al-Ṭaybī, "Alnqūd Al 'Arabia wa Intishāriha wa Athrih fì Alqrūn Elwūsța", Al-Mū 'arikh Al'arabi magazine 19 (1981), Baghdad, 201.

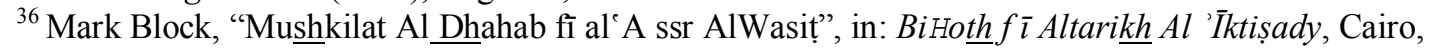
1961, 72, Amin Al-Tayby, Al-M̄̄ 'arikh Al'arabi magazine 19 (1981), 199; see the comprehensive listing of Islamic Coins found in north and east Europe, Numismatics of Islamic World, Institute for the History of Arabic - Islamic Science, Johann Wolfgang Goethe- Universitat Frankfurt Am Main, vol. 59; Islamic Coins Found in Northern and Eastern Europe, 2003.

${ }^{37}$ Ibn Faḍlan (AHmed bin Faḍlan bin Al-'Abbas bin Rashid bin Ḥammad), Resālet Ibn Faḍlan fì wasf Al RiHla ila Bilad Alturk wa Alkhzar wa Alrūs wa Alsqalibh, fì sanat 309H./921A.D, reported by Sāmī AlDahān, Beirūt, 1987, 117-118; Al-Hamawy, Yāqūt, Mujam Al-Būldan, Sader, Beirūt 1977, Part 1, 485-488.

${ }^{38}$ Referring to gold, silver, coins, jewellery and speaking money which refers to female slaves and boys.

${ }^{39}$ Al-Kardizīi, Part 2, 368.

${ }^{40}$ About the imitated coins see: Fraehn, Chr, Mar., "Drei Münzen der Wolga- Bulgharen aus dem X. Jahrhun- dertn. Chr. Erlaütert", Memoires de L'Académie Imperiale des Sciences de ST-Petersbourg, Géme Série: Sciences Politiques Histoire et Philologie I. 1832, 171- 204, pl. 1; Vasmer, Richard, Beiträge zur Muhammedanischen Münzkunde, I. Die Münzen der Abu Da'udiden, II, über die Münzen der Volga-Bulgaren. NZ (Wien) 58 (N. F. 18), 1925, 49- 84; Vasmer Richard, O Monetach Volzskich Bolgar X Veka. Izvestija Obscestva Archeologii, Istorii I Etnografii pri Kazanskom Universitate 33, 1926, 29 - 60; Rispling, Gert: The Volga Bulgarian Imitative Coinage of Al-Amir Yaltawar (Barman) and Mikail b. Jafar", Commentationes de Nummis Saeculorum IX- XI in Suecia Repertis, Nova Series, 6 (1990), pp. 275- 282.

${ }^{41}$ There are few revolutionists came out of the Samanid dynasty as AHmed bin Sahel and Lailī ibn ElNu' man(Nishabūr year 309H) But Their remain Coins are very rare and few.

${ }^{42}$ They found many dirhams and fragments in the name of IsHaq ibn AHmed among the discovery collections of European Coins or treasures, for instance dirhams Samarqand 301H. See: Fraehn, 
Recensio Numorum Muhammedanorum, 68, No. 135; Moellero J.H., "De Numis Orientalibus in Numophulacio Gothana Asservatis", Vol. 1, Numos Chaliforum et Dynastiorum Cuficos Exhibens. Gothae 1826, 111, No. 4; Fraehn, Bul- Hist. Phil., 117, No. 12; Nesselmann, G.H.F., Die Orientalischen Münzen des Akademischen Münzcabinets in Konigsberg. Leipzig 1858, 98, No. 46M., Dorn, B., "Über eine dritte dem Asiatischen Museum im J. 1869 Zugekommence Münzerwerbung", Melanges Asiatiques Tirés du Bulletin de L'Académie Impériale des Sciences de ST. Petersbourg 6, 1869- 1873 (1873) [pp. 187- 194], 189, No. 16; Markow, Inventorny Katalog Musulmanskich Monet, 124- 125, No. 305- 307; Bahrfeldt, Emil, Der Hacksilberfund Von Alexanderhof. Berliner Münzblatter 23 - 25 (N.F.I) 1902- 1904 (1905) [pp. 210- 216], 212, No. 6; Vasmer, Richard, Der Kufische Münzfund Von Friedrichshof in Estland, 61, No. 282; Østrup,J., Cataloge des Monnaies Arabes et Turques du Cabinet Royal des Medailles du Musee National de Copenhague, Copenhague 1938, No. 902. There is another example for the dirham Naysabūr 301H.; Østrup J., Cataloge des Monnaies Arabes et Turques, no.901.

${ }^{43}$ Dirham Samarqand 290H is found in Europe, Tornberg, C.J.- Hildebrand, H., Fölhagen- Fyndet, Antiquarisk Tidskrift Sverige 1870- 1873, Vol. III, 55, pl. I; Tornberg, C.J., Über Muhammedanische Revolutions, Münzen. ZDMG 1868, 705; Markow, Inventorny Katalog Musulmanskich Monet, 142, No. 729; Østrup, Cataloge des Monnaies Arabes et Turques, No. 808; Zambaur, Die Münzpragungen des Islams, 148, Not. 24.

${ }^{44}$ Nadia Haupt, National Museum of Denmark = Østrup, Cataloge des Monnaies Arabes et Turques, No.808.

${ }^{45}$ These fragments of dirhams or dinars were known as "Alqūrada"or "Alqut "”. Ibn 'A zari mentioned in the events of year $275 \mathrm{H}$ in the era of The Aghlabid ruler Ibrahītm II: "In Africa there was a combat known as dirham revolution. Ibrahim bin AHmed minted the true dirhams and cut what was dealt with from pieces (parts) the public deny it and closed the taverns and they were united. The pieces of coins were terminated from Africa till today. Ibrahim ibn AHmed minted dinars and dirhams calling it the tenth. Each dinar has ten dirhams". Ibn 'Azari Al-Marakishī, Abū Al-'Abbas: Al-Bayān Al-Mughrib fì Akhbār Al-Andalus wa Al-Maghrib,Part I, Beirūt, 1983, 120-121; The second example is from the era of 'Abbasid Caliph Al -Mustansir bl Allah, Al-Sīuțī mentioned: "The minister said: our master the prince of believers has ordered to treat you with these dirhams as a compensation of the broken gold to treat you with kindness. Saving against the treatment of the prohibited from usurious exchange, they were announced by prayer then began to be circulated in 'Iraq and priced every ten with a dinar..." Al-Sīūṭī, Galāl Al-Din Abdel RaHman, Tārikh Al Kholfa', reported by : MuHamed Muhȳi Al-Din Abd el-hamīd, Egypt, 1952, 462

${ }^{46}$ Album, A Checklist of Islamic Coins, 71, No. A 1454.

${ }^{47}$ This dirham was found in Russia see:T iesenhausen, W., Ueber Zwei Russland Gemachte Kufische Münzfunde, NZ, 1871 [pp. 166- 191], 186, No. 41. 


\section{Plates :}

1- AE. Bukhara 315H. Anonymous, Tubingen Coll. Inv. EB6E2.

2- AR. Bukhara 318H., YaHya ibn AHmed, Busso, P.Action 382 April 2005.Lot.822.W.2.95 gr.

3- AV. Naysabūr 319H.Nașr ibn AHmed, Qatar Museum Inv. 4204 .W.4.17 gr. D. $23 \mathrm{~mm}$.

4- AV. Naysabūr 319H. Nașr ibn AHmed, Qatar Museum Inv. 6007.W. 4.35 gr., D. $25 \mathrm{~mm}$.

5- AR. Naysabūr 319H. Muhamed ibn Ilyas, Private Coll. in Qatar. (Unpublished.)

6- AV. Naysabur 319H. YaHya ibn AHmed, Qatar Museum Inv.4202. W.4.30 gr., D. $23 \mathrm{~mm}$.

7- AV. Naysabūr 319H. YaHya ibn AHmed, Tubingen Coll. Inv.EB6E4.W.4.83 gr., D. $23 \mathrm{~mm}$.

8- AV. Naysabūr 319H. YaHya ibn AHmed, Baldwin's Auctions, Sale XIV, January $10^{\text {th }}$ 2007, Lot. 529. W.4.35gr., D.24mm.

9- AV. Naysabūr 319H YaHya ibn AHmed, Basle, 69 Oct.1986 , p.21, No.126.

10- AV. Naysabūr 320H. Nașr ibn AHmed, Qatar Museum Inv. 1331.W.4.28 gr., D.24mm.

11- AR. Samarqand 306H.Micael ibn Ga ' far, Nadia Haupt, National Museum of Denmark $=$ Østrup, No.939.W.2.42 gr. (Unpublished)

12- AR. Naysabur 308H. Micael ibn Ga far, Tubingen Coll. Inv.EC8C4.W.2.41 gr., D.29mm.

13- AR. NMD.Micael ibn Ga'far, Nadia Haupt, National Museum of Denmark= Østrup, No.937.W.2.95gr. (unp.)

14- AR. NMD.Micael ibn Ga'far, Nadia Haupt, National Museum of Denmark= Østrup, No.938.W.3.10gr. (unp.)

15- AV. Samarqand 301H. IsHaq ibn AHmed, Qatar Museum Inv. 4191. W.4.5 gr., D. $25 \mathrm{~mm}$.

16- AR. Samarqand 301H. IsHaq ibn AHmed, Nadia Haupt, National Museum of Denmark = Ostrup, No.902.W.3.06 gr. (Unpublished)

17- AR. Naysabūr 301H. IsHaq ibn AHmed, Nadia Haupt, National Museum of Denmark = Østrup, No.901. W.2.05 gr., fragment. (Unpublished)

18- AR. Binkath306H. YaHya ibn Ahmed, Sweden Museum in Stockholm, 8671, Gert Rispling.

19- AR. Samarqand 290H. YaHya ibn AHmed, Nadia Haupt, National Museum of Denmark $=$ Østrup, No.808.W.3.01 gr. (Unpublished)

20- AR. Samarqand 290H. YaHya ibn AHmed, Sweden Museum in Stockholm, 7063, Gert Rispling.

21- AR. Samarqand 290H. YaHya ibn AHmed, Sweden Museum in Stockholm,16200, Gert Rispling.

22- AR. Samarqand 290H. YaHya ibn AHmed, Sweden Museum in Stockholm,14782, Gert Rispling.

23- AR. Samarqand 290H. YaHya ibn AHmed, Sweden Museum in Stockholm, 3547 , Gert Rispling.

24- AR. Samarqand 290H. YaHya ibn AHmed, Sweden Museum in Stockholm, 28831, Gert Rispling.

25- AR. Samarqand 290H. YaHya ibn AHmed, Sweden Museum in Stockholm,13967 ,Gert Rispling. 


\section{Plates:}

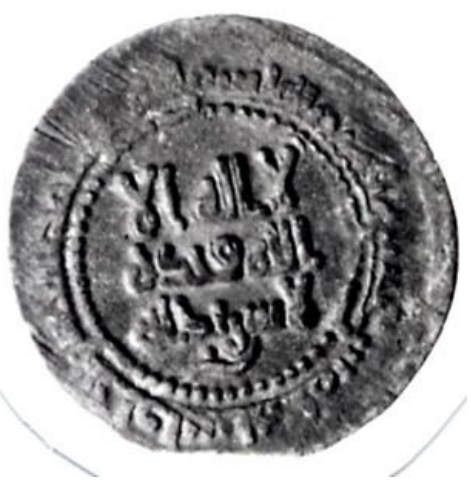

Pl. 1
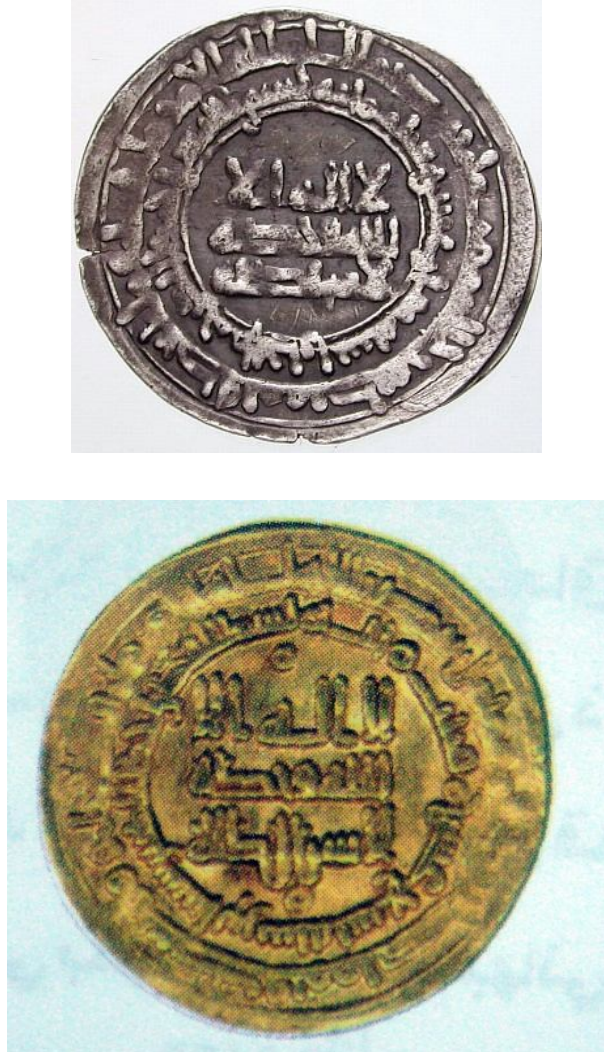

P1. 2

\section{Pl. 3a}

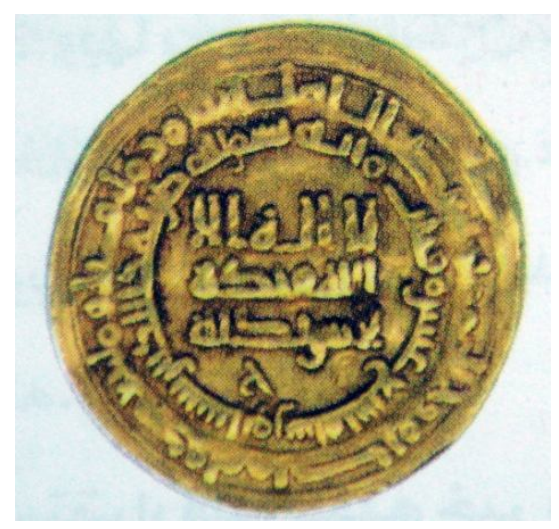

P1. 4a

Pl. 4b 


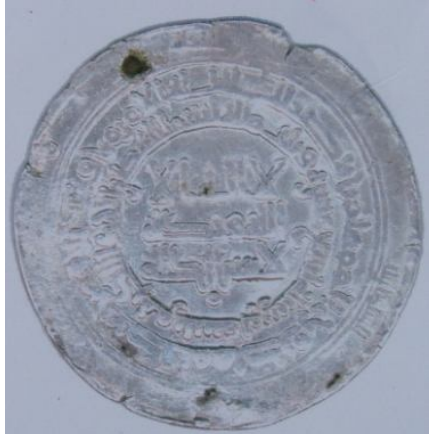

Pl. 5a

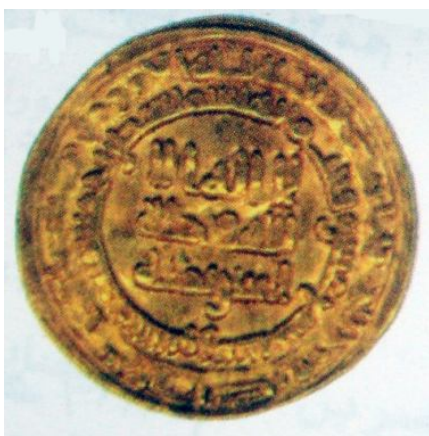

Pl. 6a
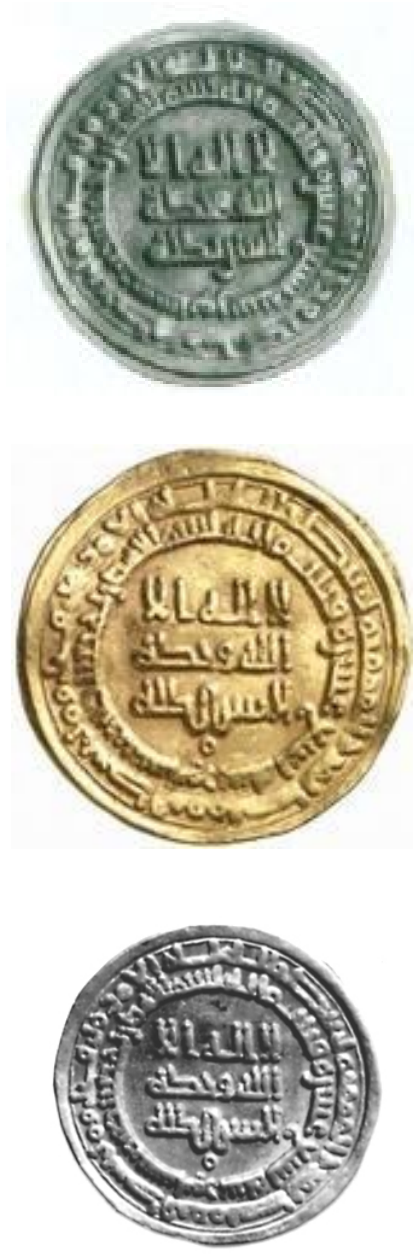

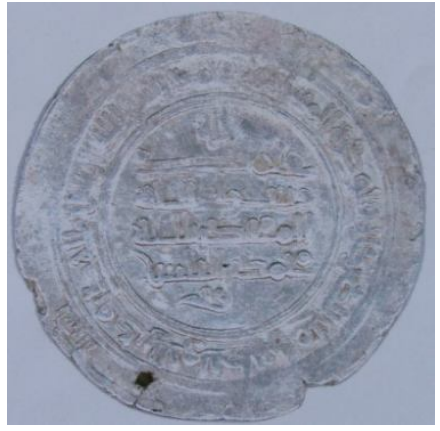

P1. 5b

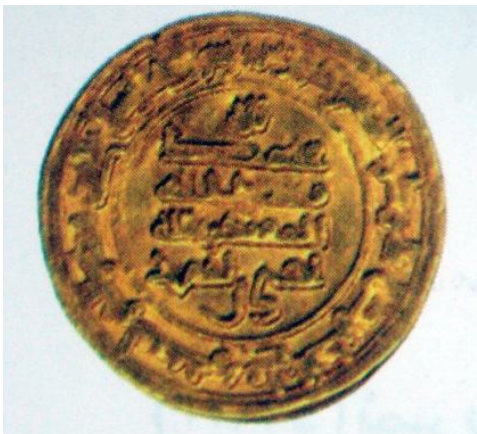

P1. 6b

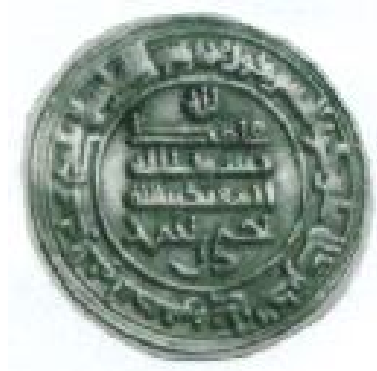

Pl. 7

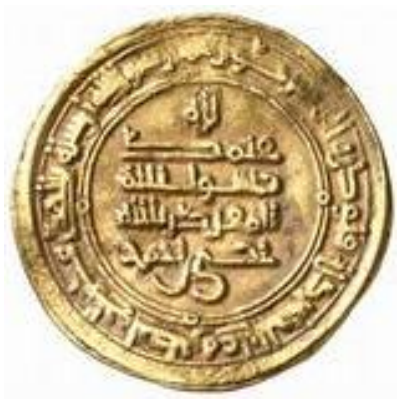

P1. 8

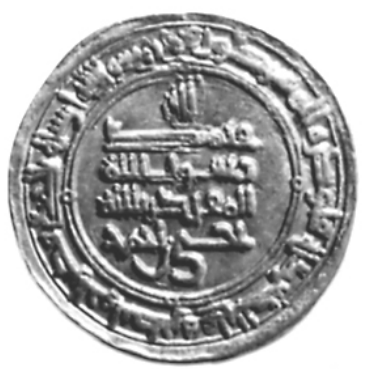

P1. 9 


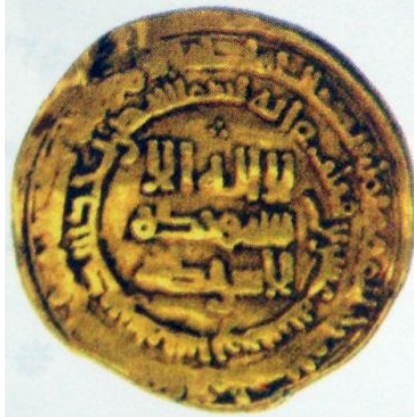

Pl. 10 a

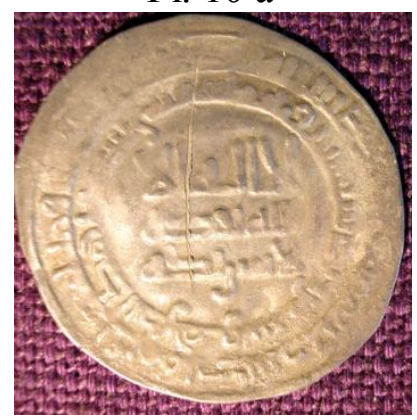

Pl. 11a
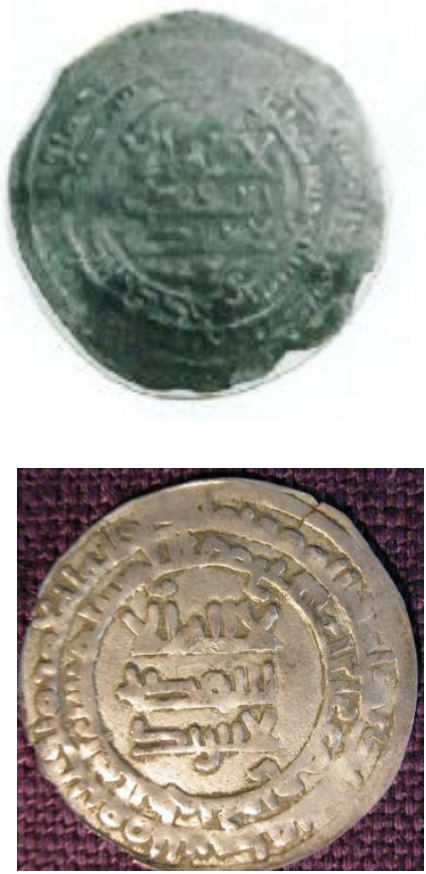

P1. 13a

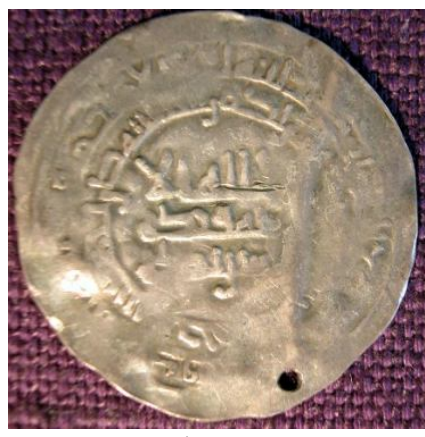

Pl. 14a

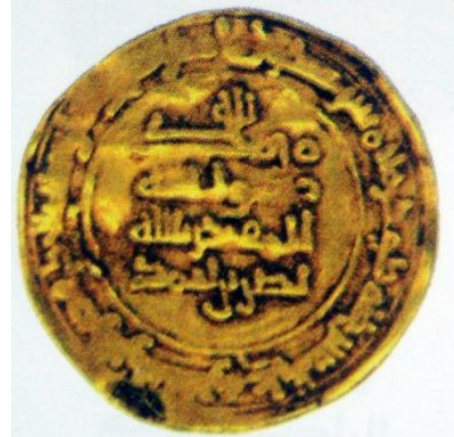

P1. $10 \mathrm{~b}$

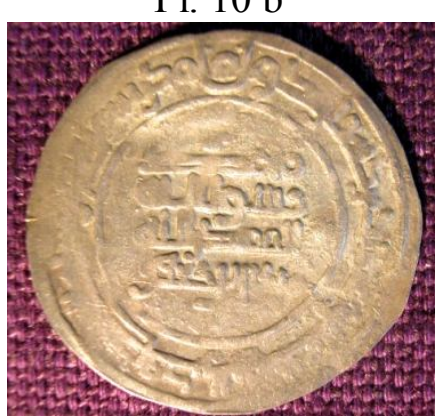

Pl. 11b

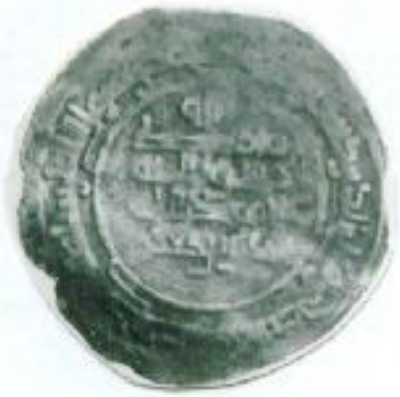

P1. 12

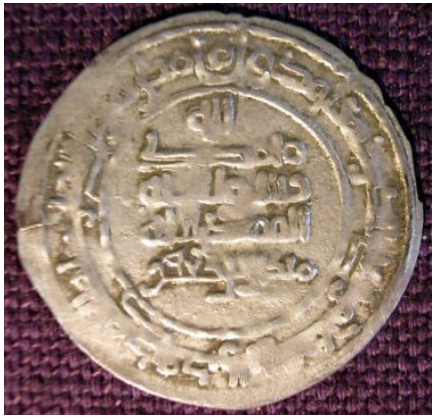

Pl. 13b

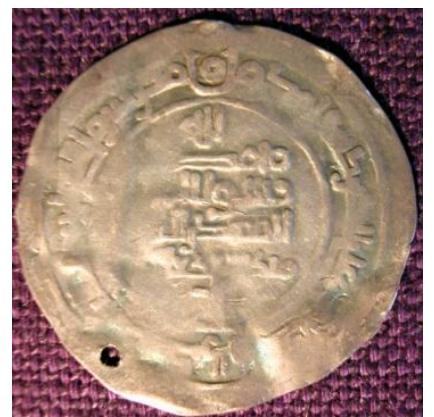

P1. $14 b$ 

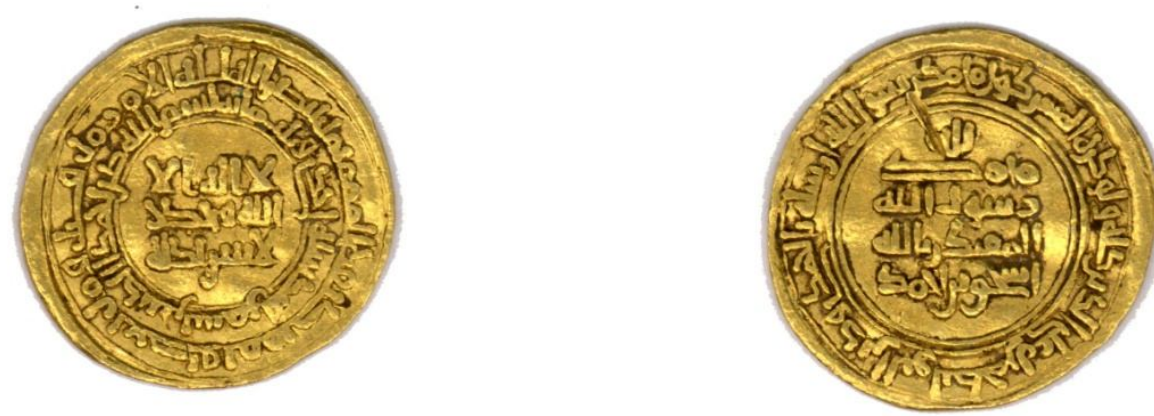

P1. 15a
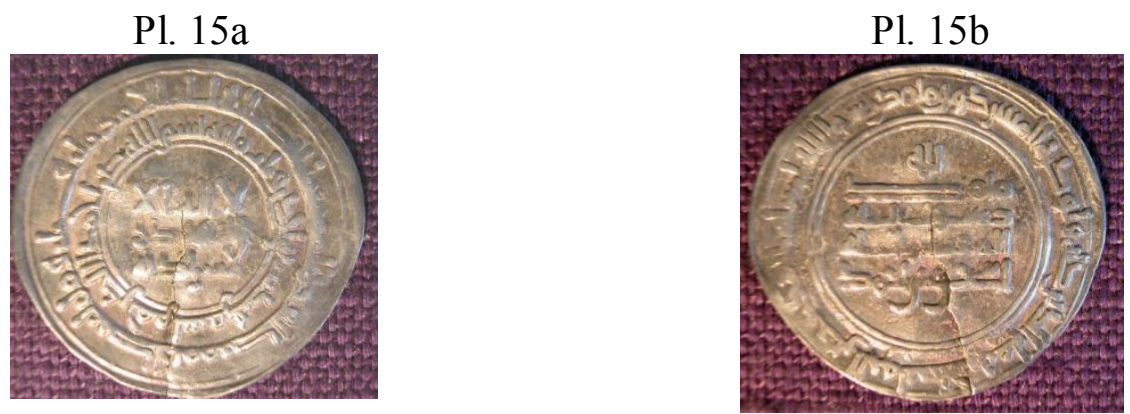

Pl. 16a

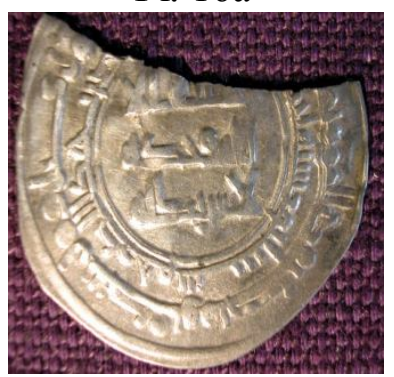

Pl. 17a

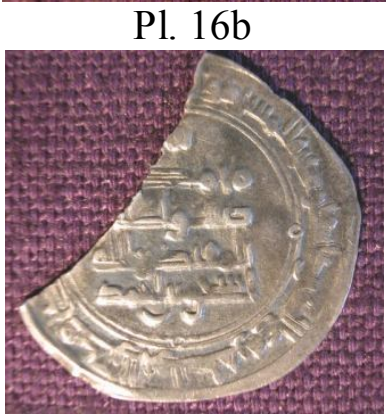

Pl. 17b

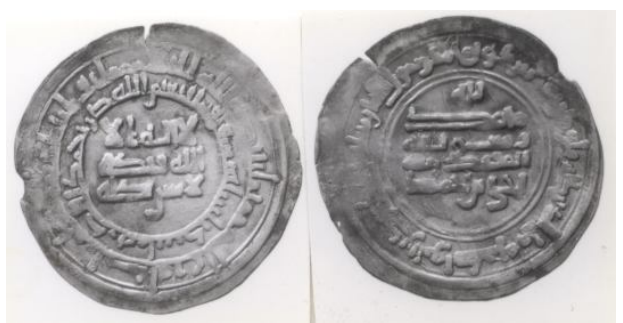

PL. 18

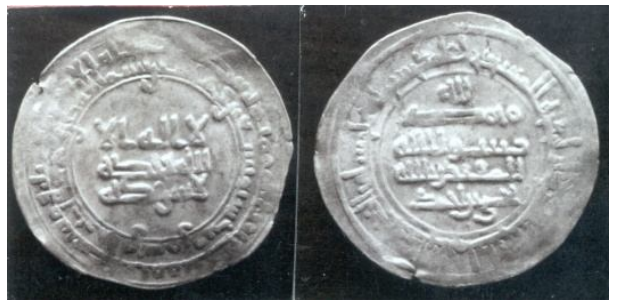

PL.19

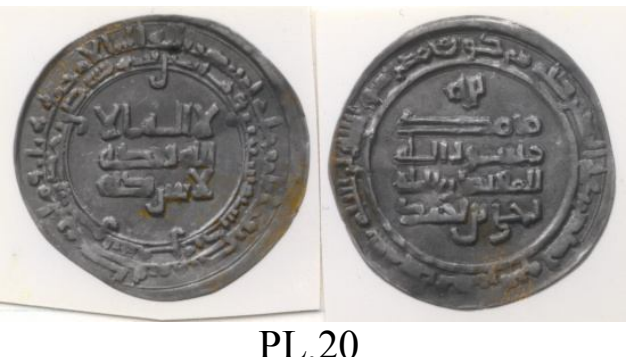




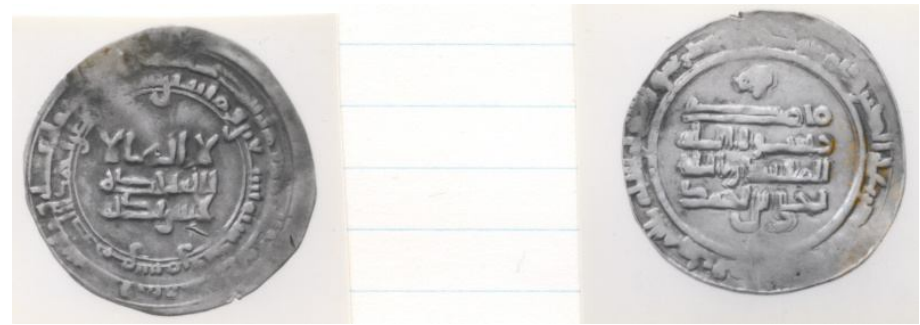

PL. 21

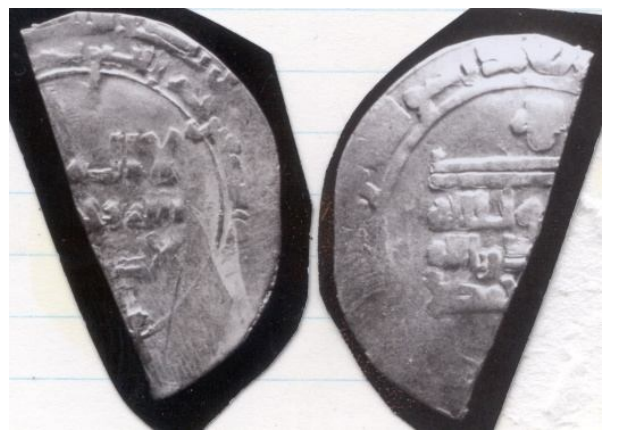

PL.22

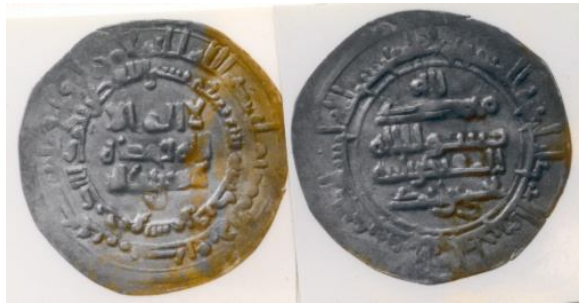

PL.23

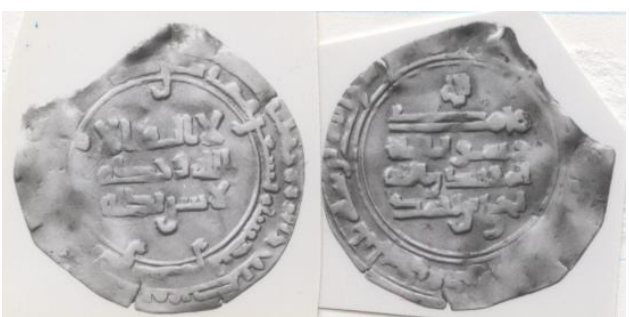

PL.24

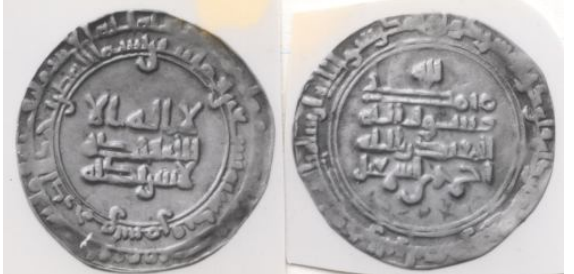

PL. 25 